\title{
Community composition of the rocky intertidal at Helgoland (German Bight, North Sea)
}

\author{
Katharina Reichert $\cdot$ Friedrich Buchholz \\ Luis Giménez
}

Received: 21 January 2008 / Revised: 8 July 2008 / Accepted: 10 July 2008 / Published online: 30 July 2008

(C) Springer-Verlag and AWI 2008

\begin{abstract}
At the rocky island of Helgoland (North Sea), the distribution and abundances of intertidal communities were assessed and the effects of wave exposure and tidal height on the spatial distribution patterns of the communities were evaluated. Macroalgae and invertebrates were sampled quantitatively along line transects in three intertidal locations, a semi-exposed, an exposed and a sheltered one. The semi-exposed location was characterised by (1) Ulva spp. at the high intertidal (Ulva-community), (2) mussels and periwinkles at the mid intertidal (Mytilus-community) and (3) Corallina officinalis and mainly the large brown alga Fucus serratus at the low intertidal (Fucuscommunity). The exposed location encompassed the mid and low intertidal; at both zones the Fucus-community occurred. The sheltered location was characterised by (1) barnacles (Balanus-community) and (2) bryozoans, hydrozoans and mainly the large brown alga Ascophyllum nodosum (Ascophyllum-community). At the semi-exposed, but not at the exposed location the communities changed with the intertidal position. A relationship between wave exposure and the occurrence of specific communities was shown
\end{abstract}

Communicated by H.-D. Franke.

Electronic supplementary material The online version of this article (doi:10.1007/s10152-008-0123-x) contains supplementary material, which is available to authorized users.

K. Reichert $(\bowtie) \cdot$ F. Buchholz

Biologische Anstalt Helgoland,

Foundation Alfred Wegener Institute for Polar and Marine

Research, 27498 Helgoland, Germany

e-mail: Katharina.Reichert@awi.de

L. Giménez

School of Ocean Sciences, University of Wales Bangor,

Menai Bridge, Anglesey LL59 5AB, UK for the sheltered location; in contrast, communities of the semi-exposed and the exposed location appear to be little influenced by wave exposure directly. The community concept and the potential causes of distribution patterns of the defined communities are discussed and suggestions for a future monitoring are given. Variations in the communities at different spatial scales speak in favour of a multiple scale sampling design to monitor changes in the intertidal communities at Helgoland.

Keywords Intertidal communities · Helgoland ·

Tidal height · Wave exposure

\section{Introduction}

Currently, a considerable research effort aims at using rocky-shore communities for ecological monitoring (e.g. Franke and Gutow 2004; Hiscock et al. 2004; Reichert and Buchholz 2006; Sánchez et al. 2005). The general objective of ecological monitoring is to collect and analyse information about the state of a system and its change in time and space related to natural fluctuations or man-induced impacts. Species composition is a well-suited parameter for ecological monitoring and is an appropriate indicator of the status of the rocky shore community as a whole (e.g. Hartnoll and Hawkins 1980; Lewis 1976; de Kluijver 1993). The limited locomotory potential, or fully sessile lifestyle, prevents the organisms to escape from short-term disturbances (e.g. desiccation, frost and toxic algal blooms) or long-term changes in the marine environment related to climate change. Furthermore, rocky shore communities are usually well accessible, are clearly arranged due to their overall two-dimensional nature, and exhibit lesser taxonomic problems than other ecosystems. 
The use of rocky shore communities for a local ecological monitoring requires a detailed knowledge of these communities (e.g. Hansen and Ingolfsson 1993; Meijer and Waardenburg 1994; Boaventura et al. 2002). To describe communities as a whole, including both algae and invertebrates, and evaluate the abundances of species, cluster analysis in combination with inverse analysis is a powerful tool (Kaandorp 1986; de Kluijver 1991, 1993; de Kluijver and Leewis 1994). With this analysis it is possible to distinguish communities, based on species composition, which is required to identify environmental factors which determine the communities and their distribution. The intertidal communities around Helgoland are located in a pivotal position for ecological monitoring. The island is located in the south-eastern North Sea, where climate is shifting towards more oceanic conditions; in particular there is evidence suggesting that the benthic community composition around the island of Helgoland (German Bight, North Sea) is changing considerably (e.g. Franke and Gutow 2004; Wiltshire and Manly 2004). The shift in North Sea climate may be an important factor driving recent changes in species composition. Many species which newly appeared at the island of Helgoland during the past decade are oceanic (southern) species which may be considered as indicators of a warming trend. The rocky shore communities of Helgoland are isolated from similar communities in the North Sea by large areas of soft sediments so that processes of change occur in a focussed way. Species assemblages of the relatively small Helgoland rocky littoral have been studied for more than a century (Harms 1993). However, all intertidal studies deal with particular taxonomic groups only or are merely semi-quantitative. For instance, a comprehensive study of invertebrate communities in the intertidal of Helgoland was carried out by Janke (1986) and repeated by Reichert and Buchholz (2006), whereas the composition of algae over the past decades was described by Bartsch and Tittley (2004). However, there is no quantitative assessment of communities as a whole, including both algae and invertebrates.

Accordingly, the specific aim of this work was to quantitatively describe the rocky shore communities at Helgoland. For this purpose, we established line transects in three rocky intertidal locations. By means of cluster and inverse analysis we identified different communities; their distribution patterns were recorded using a differential global positioning system. We used quantitative sampling along line transects in order to assess the distribution and abundances of the communities and to evaluate the effects of wave exposure as well as tidal position on the spatial distribution patterns of these communities. Based on these results we provide recommendations for a monitoring programme of the rocky shore communities at Helgoland.

\section{Methods}

Study locations and sampling design

The survey was conducted in three intertidal locations at the island of Helgoland, German Bight, North Sea $\left(54^{\circ} 11^{\prime} \mathrm{N}, 7^{\circ} 53^{\prime} \mathrm{E}\right)$ in summer 2004 . The locations were in the northern, western and southern part of the island and were named accordingly. These locations differed in wave exposure. De Kluijver (1991) used standardised gypsum blocks and took their rate of erosion as a measure for exposure; he showed that the total amount of water movement was higher at the west site of Helgoland $\left(0.14-0.16 \mathrm{~g} \mathrm{~h}^{-1}\right)$ than at the north-eastern $\left(0.14 \mathrm{~g} \mathrm{~h}^{-1}\right)$ and the southern site $\left(0.10 \mathrm{~g} \mathrm{~h}^{-1}\right)$. In shallow places at the west site the erosion rates reached $0.28 \mathrm{~g} \mathrm{~h}^{-1}$ during westerly winds (force 4-5). The prevailing winds at Helgoland are westerly (de Kluijver 1991; see Fig. 1). Therefore, we defined the western intertidal as exposed, the northern intertidal as semiexposed, and the southern intertidal as sheltered location. The geo-morphological structure of the northern location is characterised by a series of channels (mean height: ca. $-1.00 \mathrm{~m}$ referring to the height Normal Null (NN) of the German height reference system; width: ca. 3-5 m) which extend northwest towards the open sea and are separated by ridges (mean height to $\mathrm{NN}$ : ca. $-0.60 \mathrm{~m}$; width: ca. 5$15 \mathrm{~m}$ ). The ridges and channels show an alternating pattern alongshore. The western location shows similar heights and widths of channels (mean height to $\mathrm{NN}$ : ca. $-1.50 \mathrm{~m}$; width: ca. 2-20 m) and ridges (mean height to NN: ca. $-1.00 \mathrm{~m}$; width: ca. $5-25 \mathrm{~m}$ ) as the northern location, but the geo-morphological features are more irregular. The ridges form rather discrete patches enclosed by channels which remain submerged also during low tide. The southern location resulted from the construction of piers of the southern harbour in 1936. The southern location is made of concrete, whereas in the northern and western locations natural red sandstone prevails.

At the northern and western locations two line transects each were established, whereas at the southern location only one line transect was sampled as this location was smaller than the other two (see Fig. 1). Each line transect, comparable in terms of type and slope of the substratum, was selected at random from a set of possible line transects. At the northern location, one line transect was $120 \mathrm{~m}$, the other $40 \mathrm{~m}$ long. At the western location, the length of the line transects were 20 and $6 \mathrm{~m}$, respectively. The line transect at the southern location was $5 \mathrm{~m}$ long. The length of the line transects selected depended on the respective extension and exposure to wave action. Each line transect was sampled in total length by adjoining $0.25 \mathrm{~m}^{2}$ quadrats. The characteristic geo-morphological structures, present at each location, were represented by the line transects established. 
Fig. 1 a Location of Helgoland in the German Bight, North Sea, b the island with the northern, western and southern intertidal location, $\mathbf{c}-\mathbf{e}$ line transects at the northern, western and southern location. The northern and western location is shown with contours of the surface morphology and the elevation in metres refers to the height Normal Null (NN) of the German height reference system

A

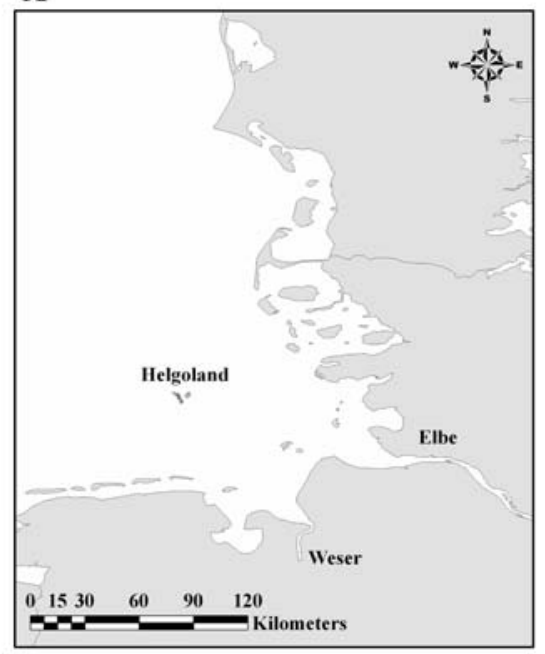

B

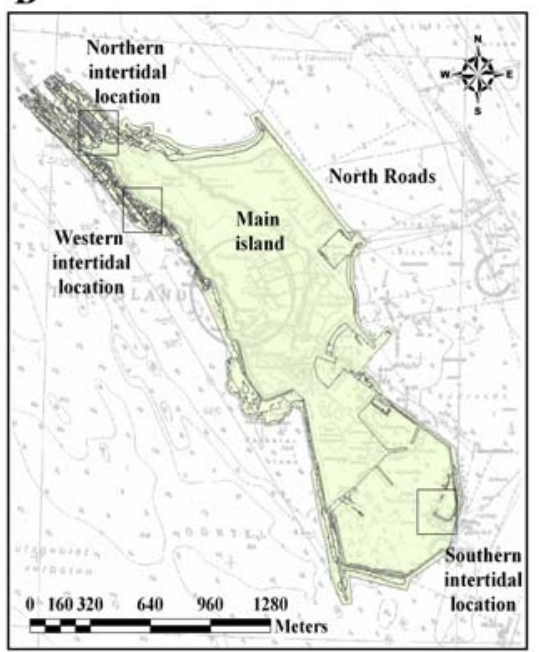

C

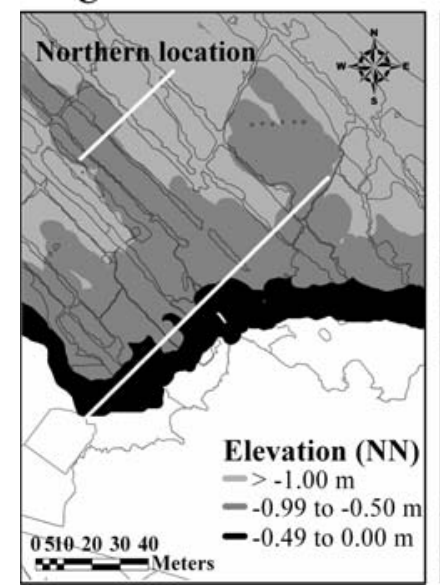

D

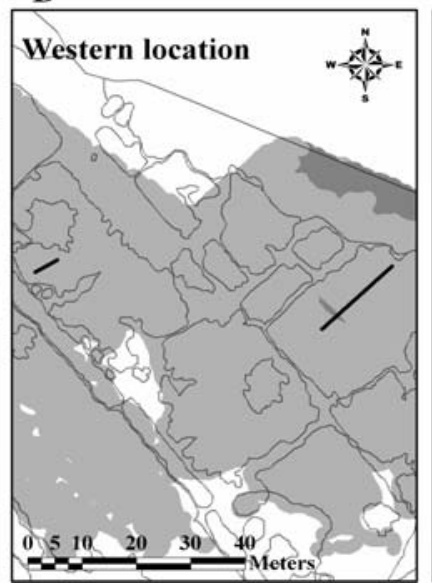

E

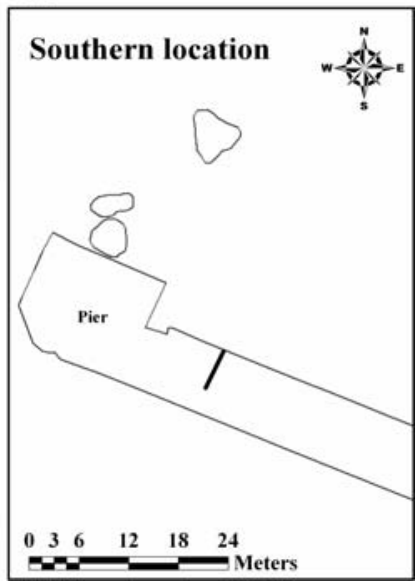

The position of every fifth quadrat was recorded using a differential global positioning system (Geo XT, Trimble, Germany) with a mean accuracy of 1-2 $\mathrm{m}$ in the field (Hennig 2004). The positions of the remaining quadrats were determined by recording their distance in situ, $x$ and $y$ spatial coordinates, in relation to the georeferenced quadrat. The coordinates taken were processed with the programme ArcGIS 9.0 (ESRI).

Site map

Figure 1 was created on the basis of georeferenced black and white $(\mathrm{b} / \mathrm{w})$ orthophotos supplied by the Department of Geomatics of the Hafen City, University Hamburg, Germany. The orthophotos were generated on a digital photogrammetric workstation DPW770 from BAE Systems (using SOCET Set software) with a ground sampling distance of $10 \mathrm{~cm}$ per pixel using aerial images with a photo scale of 1:7000 which were acquired on 26 May 2001 by WESER Bildmessflug GmbH in Bremerhaven, Germany for the Landesvermessungsamt Schleswig-Holstein in Kiel,
Germany. The digital aerial images were scanned with a resolution of $14 \mu \mathrm{m}$ which corresponds to a pixel size of $10 \mathrm{~cm}$ on the ground, by the Landesvermessungsamt using a geometrically stable photogrammetric scanner SCAI from Zeiss. Subsequently, the images were transformed from central projection into orthogonal projection by differential rectification using the orientation data of each related image and a digital elevation model (DEM) which covers the northern and western intertidal location according to the methods described in Kersten and O'Sullivan (1996).

The DEM of the b/w 1:7000 aerial images was generated by automatic digital image correlation on the DPW770 with grid spacing of $50 \mathrm{~cm}$ for the northern and western intertidal location, but not for the southern location. The image correlation algorithm used is described by Zhang and Miller (1997). Empirical accuracy investigations of the automatically generated intertidal DEM showed that the height points of the DEM have a standard deviation of $\pm 18 \mathrm{~cm}$ compared to 180 check points which were measured by geodetic methods using a Leica total station TCRA 1105 . The maximum and minimum values 
of the height differences were 40 and $-79 \mathrm{~cm}$ compared to the reference values (Lehmann 2006). The DEM refers to the height $\mathrm{NN}$ of the German height reference system (DHHN).

\section{Survey methods}

In general, the communities comprised three different structural layers: top, middle and encrusting layer. The top layer (TL) usually consisted of thalli of large brown algae (e.g. Fucus spp., Laminaria spp.). The middle layer (ML) was represented by epiphytic, epizoic and endozoic species growing erect from the substrate, but not reaching the top layer (e.g. hydrozoans, mussels, tube-building polychaetes). The encrusting layer (EL) was formed by epilithic organisms adhering directly to the substratum, such as bryozoans or encrusting algae of the genus Phymatolithon or Ralfsia (see also de Kluijver 1991, 1993, 1997).

In each structural layer, the abundance of all sessile and slow moving invertebrates as well as algae were assessed by percentage cover of the vertical projection of all species. Species of which the taxonomic position is tentative were combined to a complex. Furthermore, some species were combined into a complex if the morphological distinctions between two species were difficult to quantify or too timeconsuming to investigate (see Reichert and Buchholz 2006 for some examples).

\section{Data analyses}

\section{Community analysis}

First, we used cluster analysis to define communities in the three intertidal locations. This analysis was carried out on the abundance of all sessile and hemi-sessile algae and invertebrates of the sampled quadrats; in total 94 variables and 377 cases were analysed. The classification method based on logarithmically transformed data used the BrayCurtis similarity index and the average linkage method for clustering was applied. For the distinction of communities, the variable stopping rule was used, as it allows for differences in the mosaic species composition in different communities (de Kluijver 1997). For cluster analysis the programme PRIMER 5 was used.

Subsequently, we used an inverse analysis as described by Kaandorp (1986). We distinguished between characteristic and dominant species; characteristic species were defined as those present in at least $67 \%$ of the quadrats sampled in the community and occurring in just one community with $4 \%$ cover or more. Dominant species were defined as those present in at least $67 \%$ of the quadrats sampled in the community, but occurring in more than one community with $4 \%$ cover or more.
Characteristic and dominant species are listed in Table 1 whereas species which did not meet our definition of characteristic and dominant species, but also occurred in one or more communities are shown in Supplement 1. The sequence of species in Table 1 is based on the dendrogram (Fig. 2). (1) The community which combined with the remaining communities at the lowest similarity (community$\mathrm{X}$ ) was considered first, followed by that community which combined at the second-lowest similarity with the remaining communities (community-XX), etc. (2) Those characteristic and dominant species which occurred in community-X and at least one other community were listed first, followed by those characteristic and dominant species restricted to community-X; then, those species that occurred in community$\mathrm{XX}$ and at least one other community were listed, followed by those species restricted to community-XX, etc.

\section{Communities related to environmental factors}

We evaluated if wave exposure as well as tidal height constrained the occurrence of communities at the locations. For the relationship between wave exposure and distribution of communities we calculated and compared the relative occurrence of communities at the semi-exposed (northern), exposed (western) and sheltered (southern) location.

For the relationship between tidal height and species composition of communities we calculated the relative occurrence of communities per tidal height at the northern and western location. We extracted the tidal height for each georeferenced quadrat at the northern and western location from the prevailing intertidal digital elevation model with the programme ArcGIS 9.0 (ESRI). Thereafter, we assigned the community of each quadrat to one of the three categories of tidal height: (1) 0 to $-0.49 \mathrm{~m}$, (2) -0.5 to $-0.99 \mathrm{~m}$, (3) -1 to $-1.49 \mathrm{~m}$ referring to the height $\mathrm{NN}$ of the German height reference system. We defined the categories as the high, mid and low intertidal, respectively. For the quadrats in the southern location no intertidal digital elevation model was available, and consequently those communities could not be assigned to any categories of tidal height.

\section{Classification of communities}

Based on the community analysis and the relationship between the community patterns and the patterns of the environmental factors, we classified the communities by names, which were labelled with roman numerals up to this point. For the classification we combined species composition of the communities and the environmental factors which may determine their distribution (wave exposure, tidal height on the shore, substratum type). We used characteristic and dominant species restricted to a specific community, except of species which show a strong seasonality. Community-III was 
Table 1 Mean percentage covI-VI

Bold values indicate a presence level of at least $67 \%$ of a certain species within the community. Characteristic and dominant species restricted to a certain community are in bold italics. Mean percentage cover of bare rock and total species richness is additionally shown

$E L$ encrusting layer

Abbreviations in brackets indicate higher taxonomic groups as Phaeophyceae, $R h$ Rhodophyceae, $C n$ cnidarians, $G a$ gastropods, $B i$ bivalves, $A n$ annelids, $\mathrm{Cr}$ crustaceans, $\mathrm{Br}$ bryozoans er of species within communities follows: $C h$ Chlorophyceae, $P h$

\begin{tabular}{|c|c|c|c|c|c|c|}
\hline & I & II & III & IV & $\mathrm{V}$ & VI \\
\hline Thoracica $(\mathrm{Cr})$ & 0.01 & 0.75 & 0.29 & 0.86 & 0.00 & 20.00 \\
\hline Blidingia minima $(\mathrm{Ch})$ & 0.00 & 0.00 & 0.00 & 0.00 & 0.00 & 17.00 \\
\hline Fucus spiralis $(\mathrm{Ph})$ & 0.86 & 0.26 & 0.00 & 1.43 & 0.00 & 15.00 \\
\hline Porphyra spp. (Rh) & 0.01 & 0.00 & 0.00 & 0.00 & 0.00 & 5.25 \\
\hline Ulva spp. (Chloro) & 59.24 & 0.58 & 0.02 & 0.14 & 3.77 & 1.25 \\
\hline Fucus serratus $(\mathrm{Ph})$ & 14.03 & 34.90 & 79.67 & 79.71 & 26.36 & 0.00 \\
\hline EL-Phymatolithon lenormandii (Rh) & 0.60 & 24.28 & 34.06 & 40.71 & 9.32 & 0.00 \\
\hline Chondrus crispus (Rh) & 0.53 & 20.13 & 15.59 & 6.36 & 13.00 & 0.00 \\
\hline Cladophora rupestris $(\mathrm{Ch})$ & 0.08 & 0.58 & 2.92 & 26.71 & 16.59 & 20.00 \\
\hline Rhodothamniella floridula (Rh) & 0.03 & 0.01 & 0.00 & 2.79 & 16.55 & 2.50 \\
\hline Spongomorpha $\operatorname{arcta}(\mathrm{Ch})$ & 0.05 & 0.00 & 0.00 & 0.00 & 10.27 & 0.00 \\
\hline Tubicolous organisms (An/Cr) & 0.80 & 0.56 & 0.54 & 0.29 & 4.91 & 0.00 \\
\hline Ulva lactuca $(\mathrm{Ch})$ & 4.06 & 0.35 & 2.38 & 0.14 & 27.18 & 0.00 \\
\hline EL-Cryptosula pallasiana $(\mathrm{Br})$ & 0.00 & 0.01 & 0.26 & 15.86 & 0.00 & 0.00 \\
\hline Dynamena pumila $(\mathrm{Cn})$ & 0.00 & 0.08 & 0.66 & 4.14 & 0.18 & 1.00 \\
\hline Ascophyllum nodosum $(\mathrm{Ph})$ & 0.00 & 0.00 & 0.00 & 44.93 & 0.00 & 30.00 \\
\hline Corallina officinalis (Rh) & 0.01 & 0.56 & 7.67 & 0.00 & 3.67 & 0.00 \\
\hline Rhizoclonium tortuosum (Ch) & 0.22 & 21.50 & 0.73 & 0.00 & 0.00 & 0.00 \\
\hline Mytilus edulis (Bi) & 0.04 & 5.91 & 1.20 & 0.14 & 0.05 & 0.00 \\
\hline Littorina littorea $(\mathrm{Ga})$ & 0.19 & 5.68 & 0.97 & 0.00 & 0.09 & 0.00 \\
\hline EL-Ralfsia verrucosa $(\mathrm{Ph})$ & 4.03 & 16.85 & 1.00 & 0.00 & 0.05 & 0.00 \\
\hline Bare rock & 32.63 & 22.06 & 20.10 & 2.57 & 17.73 & 25.00 \\
\hline Total species richness & 34 & 44 & 60 & 32 & 37 & 11 \\
\hline
\end{tabular}

Fig. 2 Dendrogram of line transects surveyed in the northern, western and southern location, based on cluster analysis. Clusters distinguished are marked I-VI; please note that the roman numerals are in reverse order (from right to left)

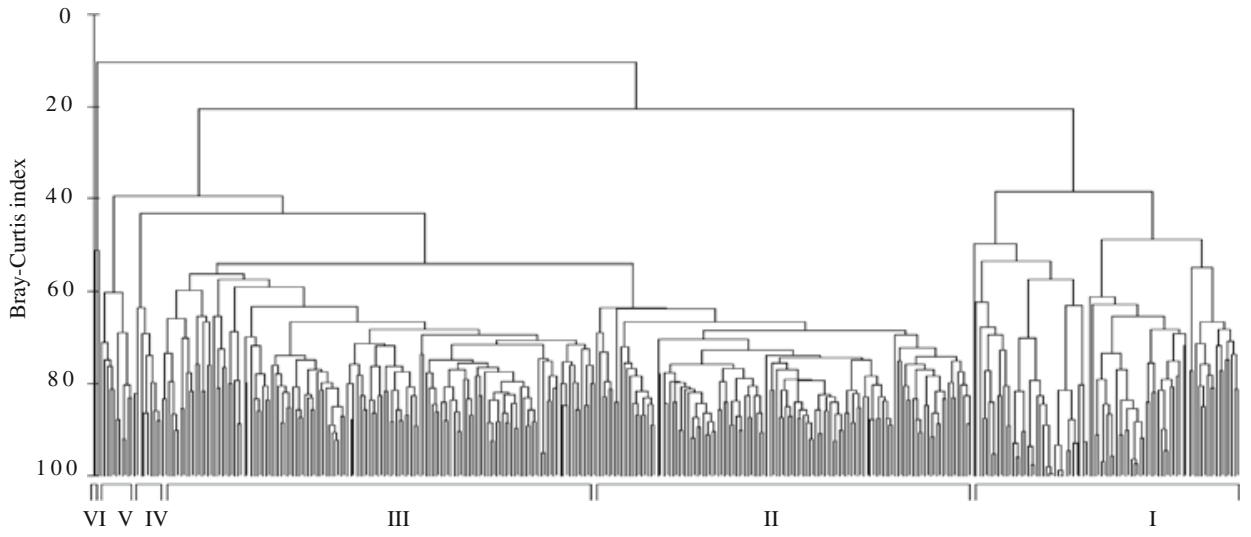

a further exception; here, we added one dominant species which was not restricted to this community. The short names of the communities were defined by one of those species. The selected species was conspicuous at first sight due to its size and/or its non-patchy distribution pattern.

\section{Results}

In the dendrogram six main clusters of quadrats were distinguished (Fig. 2). The first three clusters (I, II and III) consisted of 88 (cluster I) up to 144 sampled quadrats (cluster
III), whereas clusters IV, V and VI related to eleven quadrats (cluster V) or less. Cluster VI already combined at a similarity of about $10 \%$ with the other clusters, followed by cluster I which combined with the remaining clusters (II-V) at $20 \%$ similarity. Clusters II and III showed a similarity of about $50 \%$. The six meaningful clusters were regarded as intertidal communities which are described in the following.

Species composition of communities

First, species were mentioned which were dominant in several communities. Then, communities were described on 
the basis of characteristic species and dominant species restricted to a specific community.

Species dominant in several communities were the brown alga Fucus serratus, the red algae Phymatolithon lenormandii and Chondrus crispus as well as the green alga Cladophora rupestris (Table. 1). F. serratus, P. lenormandii and C. crispus were dominant in communities II-V; in communities IV and V C. rupestris occurred additionally as dominant species.

Community VI was characterised by species of Thoracica, the green alga Blidingia minima, the brown alga Fucus spiralis and species of the genus Porphyra (Table. 1). In community I species of the genus Ulva were characteristic. In community V the red alga Rhodothamniella floridula, the seasonal green alga Spongomorpha arcta and tube-building polychaetes were characteristic, and the green alga Ulva lactuca was only dominant in community V. Community IV as characterised by the encrusting bryozoan Cryptosula pallasiana and the hydrozoan Dynamena pumila; the large brown alga Ascophyllum nodosum was the dominant species restricted to community IV. For community III, the red alga Corallina officinalis was the characteristic species. Community II was characterised by the seasonal green alga Rhizoclonium tortuosum, the blue mussel Mytilus edulis and the periwinkle Littorina littorea; the dominant species restricted to community II was the encrusting brown alga Ralfsia verrucosa.

The highest mean percentage cover of bare substrate occurred with about $33 \%$ in community I and only $2.6 \%$ of the substrate was un-colonised in community IV. The total number of species was highest in community III (21 algae and 39 invertebrates), whereas in community VI only 11 species appeared (Table 1).

Communities related to environmental factors

The semi-exposed (northern) location was characterised by communities I-III (Fig. 3), and exhibited a zonation with (1) community I at the high intertidal, (2) community II and III at the mid intertidal, and (3) community III at the low intertidal (Fig. 4a). The exposed (western) location was characterised by communities I, III and V, whereas communities IV and VI characterised the sheltered (southern) location (Fig. 3). In the western location communities I and $\mathrm{V}$ only occurred at the low intertidal, whilst community III also occurred with $<20 \%$ at the mid intertidal (Fig. 4b).

\section{Classification of communities}

Community I was classified as the Ulva spp. community which occurred mostly at the high-shore of the semiexposed (northern) location (Table 2). Community II was named after the main occurrence of Mytilus edulis-Litto-

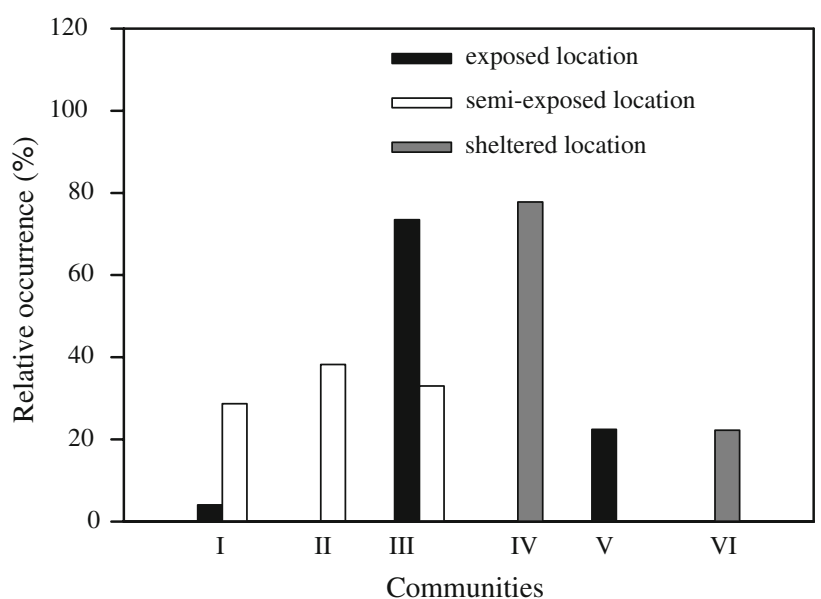

Fig. 3 Relative occurrence of communities I-VI at the exposed, semiexposed and sheltered intertidal location

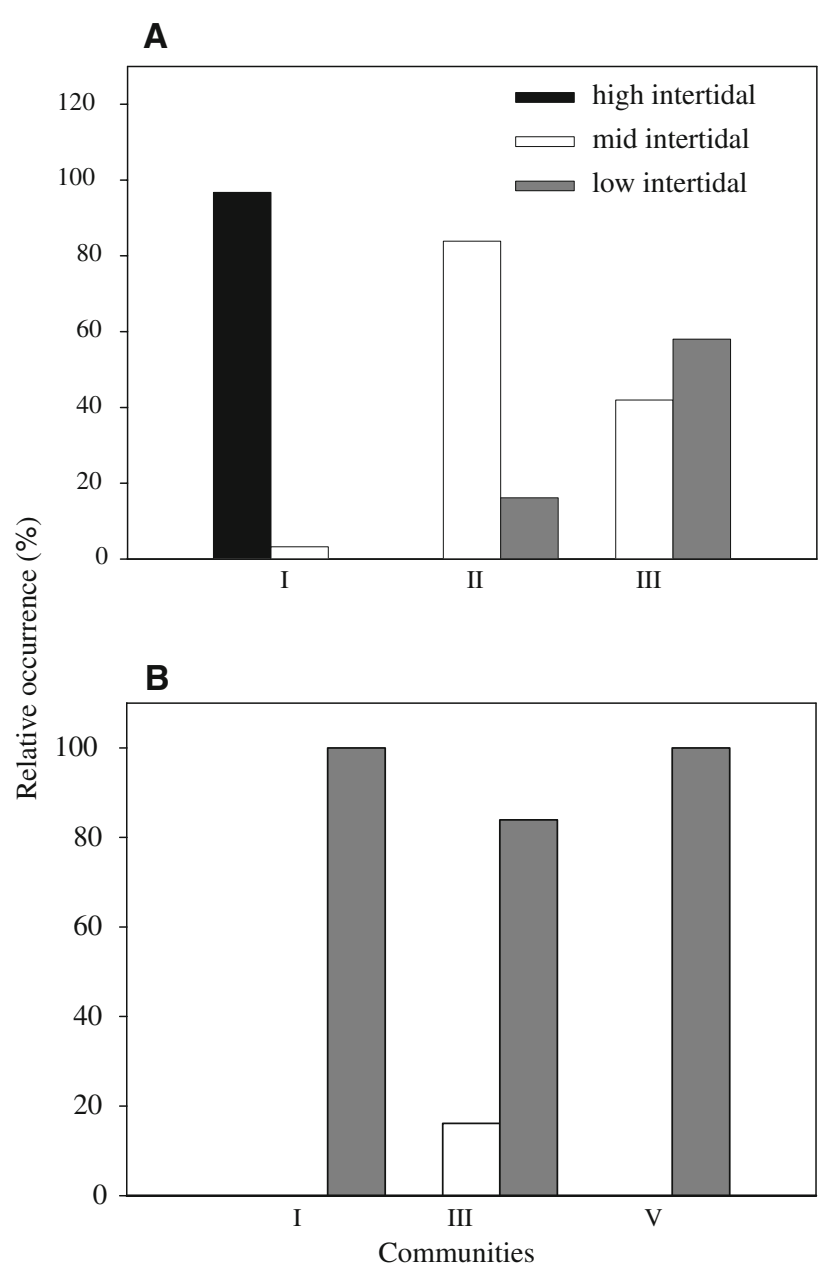

Fig. 4 Relative occurrence of the communities at the high, mid and low intertidal zone of the semi-exposed (a) and the exposed location (b)

rina littorea-Ralfsia verrucosa at the mid-shore of the semi-exposed (northern) location. Community III was classified as the Corallina officinalis-Fucus serratus commu- 


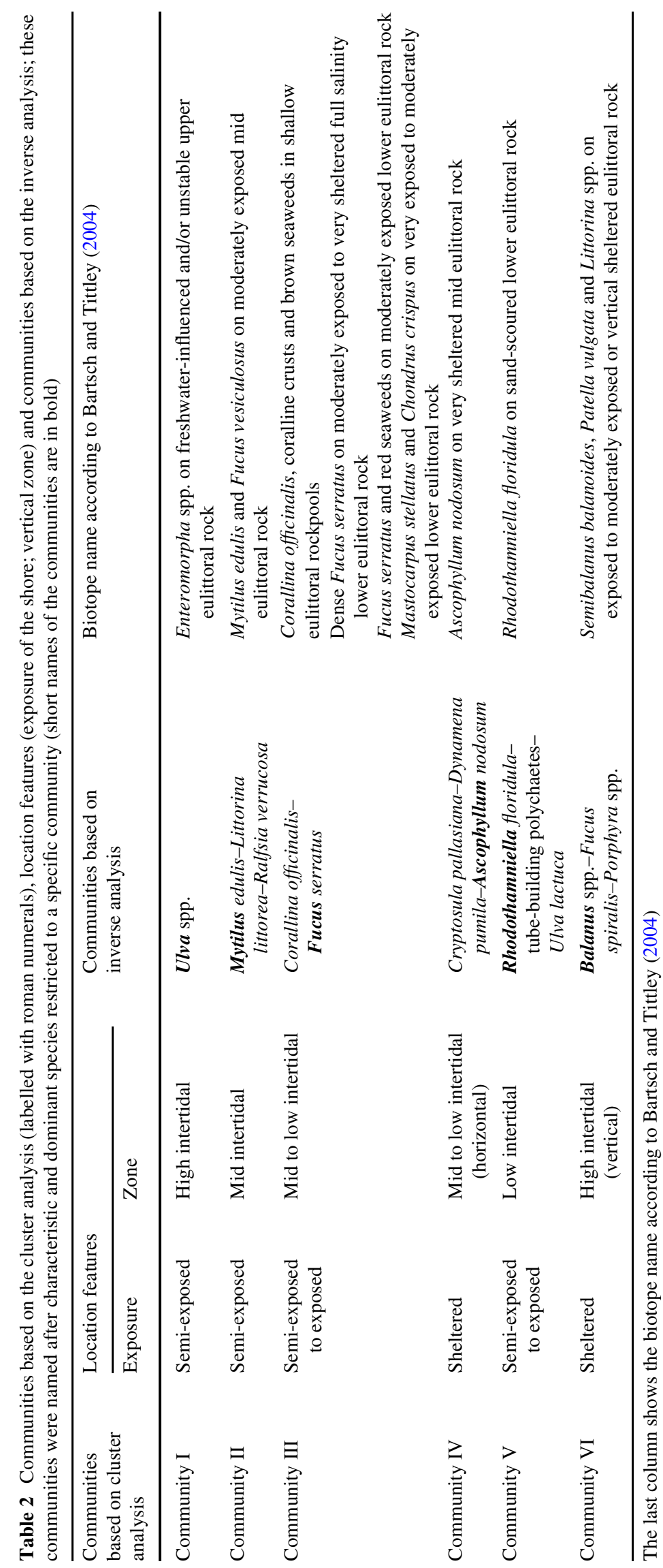


nity which occurred at the mid- and low-shore of the exposed (western) and semi-exposed (northern) location. Community IV was named after the restricted occurrence of Cryptosula pallasiana-Dynamena pumila-Ascophyllum nodosum to horizontal sites of the harbour pier at the sheltered (southern) location. Community $\mathrm{V}$ was classified as the Rhodothamniella floridula-tube-building polychaetesUlva lactuca community restricted at the low-shore of the western and northern location, and community VI was named after the restricted occurrence of Balanus spp.Fucus spiralis-Porphyra spp. to vertical sea walls at the sheltered (southern) location.

\section{Discussion}

The present study provides quantitative information on species composition and their relation to environmental factors at three locations at Helgoland. In total six intertidal communities were defined. The information obtained from the present study has clarified and set a base line with regard to (1) the distribution and abundances of the communities and (2) the effects of wave exposure and tidal height on these communities. We will first take up the discussion about the community concept and will explain what definition of communities we used in the present study. Then, we will discuss the distribution of the defined communities in terms of wave exposure and tidal height or other possible regulating factors, and finally suggestions for a future monitoring will be given.

Two main lines of thought have evolved in various forms to understand the distribution patterns of marine benthic alga and invertebrate assemblages: the "level bottom" and the "zonation" approach (Erwin 1983). An early attempt to classify the marine benthos communities according to the "level bottom" approach was carried out by Petersen (1914). He characterised the benthic communities by dominant species and related those to water depth and sediment structure. Parallel to the "level bottom" approach, the "zonation" approach was developed which has often been applied in the intertidal (Erwin 1983). This school of thought has its origin in the observations of distinct bands of intertidal algae and invertebrates and relates the assemblages to a physical gradient or to a series of physical gradients which may or may not overlap (Stephenson and Stephenson 1949, 1972; Lewis 1978). In the "zonation" approach the evident bands or zones are not due to different species assemblages having the same starting and end points in their occurrence related to physical gradients. The zone is usually characterised by one or at most a few species (Erwin 1983). These species make this zone obvious in some way and can be considered as relatively constant assemblages with a number of less obvious species occur- ring in the same zone. Thus, for ecological monitoring, i.e. for a systematic survey undertaken to provide an observation series in time, the definition of communities according to the "zonation" approach with relatively constant entities of species is preferable. Ecological monitoring, which is under way at the Helgoland intertidal, aims at a comparison in time based on the similarity between entities of species. Therefore, our definition of communities used here is a directly or indirectly interacting assemblage of algae and invertebrates which remains stable in time under a given set of abiotic factors. This classification allows to recognise different intertidal communities and to identify changes within its elements (de Kluijver 1997). In this concept, biotic interactions are not negated, but compared to the regulation by the physical environment they are considered of minor importance. To test such assumptions, the next step may be seen in manipulative experiments aiming at clarifying if the communities defined have similar preferences for a certain set of abiotic conditions or if they are structured predominantly by biological interactions.

When we considered the differently exposed intertidal locations, we concentrated on those communities which only occurred in one of the study locations, since this implies that wave exposure is a potential regulating factor for the distribution observed. The occurrence of the Balanus- and the Ascophyllum-community was restricted to the sheltered location, and both communities differed from all other communities by stands of the large brown alga Ascophyllum nodosum. The restricted occurrence of Ascophyllum nodosum on sheltered harbour walls is in agreement with the biotope classification by Bartsch and Tittley (2004). They identified records of A. nodosum on the south harbour seawalls not directly exposed to wave action. The restricted occurrence of abundant stands of $A$. nodosum in the southern study location suggests that the settlement and recruitment success of $A$. nodosum may be enhanced by sheltered conditions. Experiments by Vadas et al. (1990) showed that wave action is a major source of mortality to recently settled zygotes of A. nodosum. On the other hand, the restricted occurrence of the dense stands of A. nodosum could also be a direct result of substratum type. At the southern location, the harbour walls are made of concrete, whilst at the northern and western study locations mainly red sandstone appears. However, several studies have shown that $A$. nodosum also occurs abundantly on granite, limestone, basalt (Hartnoll and Hawkins 1985; Dudgeon and Petraitis 2001; Lindegarth et al. 2001). It therefore seems unlikely that the factor substratum type was important for the restricted occurrence of the A. nodosum-community at the southern location.

The Mytilus-community occurred only at the semiexposed (northern) location. This agrees with the biotope classification by Bartsch and Tittley (2004). However, on 
other rocky coasts the blue mussel Mytilus edulis are widely distributed from sheltered to exposed areas (Janke 1990; Lintas and Seed 1994; Dudgeon and Petraitis 2001). Therefore, the occurrence of the Mytilus-community does not seem to be associated with the factor wave exposure, but may rather be a result of biotic factors such as grazing and competition for space (Janke 1990). The occurrence of the characteristic mussel patches seems to be related to a very high local abundance of the periwinkle $L$. littorea. The increased grazing by littorinids may prevent the establishment of dense stands of macroalgae, particularly Fucus species, and thus in turn may favour the establishment of mussels which compete for space with macroalgae (e.g. Menge 1976; Menge and Sutherland 1976; Lubchenco 1983).

Besides the communities which were restricted to the sheltered and semi-exposed location, respectively, the Rhodothamniella-community was recorded only at the exposed (western) rock-platform. However, further observations showed that this community also occurred at the semiexposed (northern) rock-platform, but was absent from the established line transects. This observation agrees with the biotope classification by Bartsch and Tittley (2004). They classified the cushion-forming "Rhodothamniella floridula" biotope under the biotope complex of barnacles and fucoids on moderately exposed shores.

As a further step, next to the potential causes for the variation in communities among the three locations, we compared the distribution patterns of the communities at a smaller spatial scale, across the rock-platform of the northern and western location. Changes in communities at the northern location are related to variations in tidal height. A high, mid and low intertidal was found consisting of distinct horizontal bands of specific communities: the Ulva-community at high-shore, the Mytilus-community at mid-shore and the Fucus-community at low-shore. Such distinct patterns of vertical zonation with different composition of species in the high, mid and low intertidal were already reported semiquantitatively for invertebrates (Janke 1986; Reichert and Buchholz 2006) and for macroalgae (Bartsch and Tittley 2004) across the northern rock-platform at Helgoland. Accordingly, the occurrence of the different communities at different intertidal heights could be expected. However, this spatial zonation pattern relating to tidal height was only observed at the northern location. At the western location, the tidal height does not vary much; only two categories of tidal height, the mid and low intertidal, occurred. Due to the construction of the seawall along the western part of the island, the extension of the natural rock-platform of the intertidal is reduced resulting in a lack of typical high-shore assemblages at the western location. Moreover, the mid and low intertidal was not dominated by zonal communities differing in species composition: the western intertidal was mainly distinguished by the Fucus-community, characterised by Coralina officinalis and dominated by Fucus serratus and red algae (e.g. Phymatolithon lenormandii and Chondrus crispus). This may suggest that in the western location different alga and invertebrate assemblages are mainly distributed in patches within zones thus forming a mosaic community (Menge et al. 1993). In recent years, it has been realised that most intertidal algae and invertebrates are distributed extremely patchy within any height on rocky shores (Aberg and Pavia 1997; Benedetti-Cecchi 2001; Chapman 2002; Fraschetti et al. 2005). Dependent on the geo-morphological structures of rocky shores, a variety of pools, crevices and cracks results in diverse small-scale variation in physical conditions (e.g. micro-hydrodynamic or micro-climate changes) and therefore in small-scale variation of behavioural responses. The occurrence of patchily distributed species assemblages, next to typical zonation patterns, may also be assumed for the Helgoland intertidal, and thus should be tested in further studies.

For a future monitoring at Helgoland, we suggest an improved sampling design which incorporates a variety of the communities classified here. Focusing on a single community would possibly lead to a loss of significant information. Whether the communities are relatively stable in time or undergo a succession cannot be answered by the present study. The current long-time monitoring is necessary to shed light on the temporal stability of these communities. Moreover, a more profound understanding of the scalesdependent distribution patterns is vital to explaining the variation in the intertidal communities at Helgoland. Experimental studies should be designed to investigate the factors causing distribution patterns, their intensities and rates at relevant rather than arbitrary scales.

Acknowledgments This work is part of the Ph.D. thesis of Katharina Reichert conducted at the Biological Station Helgoland, Foundation Alfred Wegener Institute for Polar and Marine Research. The authors are grateful to Dr. Mario de Kluijver for his ideas, discussion and help of handling the analysis. Dr. Inka Bartsch and Prof. Thomas Kersten provided the digital aerial images as well as a digital elevation model of the intertidal locations at Helgoland. Anja Röw is thanked for assistance in the field.

\section{References}

Aberg P, Pavia H (1997) Temporal and multiple scale spatial variation in juvenile and adult abundance of the brown alga Ascophyllum nodosum. Mar Ecol Prog Ser 158:111-119

Bartsch I, Tittley I (2004) The rocky intertidal biotopes of Helgoland: present and past. Helgol Mar Res 58:289-302

Benedetti-Cecchi L (2001) Variability in abundance of algae and invertebrates at different spatial scales on rocky sea shores. Mar Ecol Prog Ser 215:79-92

Boaventura D, Ré P, Cancela da Fonseca L, Hawkins SJ (2002) Intertidal rocky shore communities of the continental Portuguese coast: analysis of distribution patterns. Mar Ecol 23:69-90 
Chapman MG (2002) Patterns of spatial and temporal variation of macrofauna under boulders in a sheltered boulder field. Aust Ecol 27:211-228

De Kluijver MJ (1991) Sublittoral hard substrate communities off Helgoland. Helgoländer Meeresunters 45:317-344

De Kluijver MJ (1993) Sublittoral hard-substratum communities off Orkney and St Abbs (Scotland). J Mar Biol Assoc UK 73:733-754

De Kluijver MJ (1997) Sublittoral communities of North Sea hardsubstrata. Ph.D. dissertation, University of Amsterdam, The Netherlands

De Kluijver MJ, Leewis RJ (1994) Changes in the sublittoral hard substrate communities in the Oosterschelde Estuary (SW Netherlands), caused by changes in the environmental parameters. Hydrobiologia 282-283:265-280

Dudgeon S, Petraitis PS (2001) Scale-dependent recruitment and divergence of intertidal communities. Ecology 82:991-1006

Erwin DG (1983) The community concept. In: Earll R, Erwin DG (eds) Sublittoral ecology: the ecology of the shallow sublittoral benthos. Clarendon Press, Oxford, pp 144-164

Franke HD, Gutow L (2004) Long-term changes in the macro-zoobenthos around the rocky island of Helgoland (German Bight, North Sea). Helgol Mar Res 58:303-310

Fraschetti S, Terlizzi A, Benedetti-Cecchi L (2005) Patterns of distribution of marine assemblages from rocky shores: evidence of relevant scales of variation. Mar Ecol Prog Ser 296:13-29

Hansen JR, Ingolfsson A (1993) Patterns in species composition of rocky shore communities in sub-arctic fjords of eastern Iceland. Mar Biol 117:469-481

Harms J (1993) Check list of species (algae, invertebrates and vertebrates) found in the vicinity of the island of Helgoland (North Sea, German Bight)-a review of recent records. Helgoländer Meeresunters $47: 1-34$

Hartnoll RG, Hawkins SJ (1980) Monitoring rocky-shore communities: a critical look at spatial and temporal variation. Helgoländer Meeresunters 33:484-494

Hartnoll RG, Hawkins SJ (1985) Patchiness and fluctuations on moderately exposed shores. Ophelia 24:53-64

Hennig B (2004) Applications of hyperspectral remote sensing in coastal ecosystems: a case study from the German North Sea. MS Thesis, University of Cologne, Germany

Hiscock K, Southward AJ, Tittley I, Hawkins SJ (2004) Effects of changing temperature on benthic marine life in Britain and Ireland. Aquat Conserv 14:333-362

Janke K (1986) Die Makrofauna und ihre Verteilung im Nordost-Felswatt von Helgoland. Helgoländer Meeresunters 40:1-55

Janke K (1990) Biological interactions and their role in community structure in the rocky intertidal of Helgoland (German Bight, North Sea). Helgoländer Meeresunters 44:219-263

Kaandorp JA (1986) Rocky substrate communities of the infralittoral fringe of the Boulonnais coast, NW France: a quantitative survey. Mar Biol 92:255-265

Kersten T, O’Sullivan W (1996) Project SWISSPHOTO-digital orthophotos for the entire area of Switzerland. Int Arch Photogr Remote Sens 31:186-191
Lehmann V (2006) Empirische Genauigkeitsuntersuchungen digitaler Geländemodelle verschiedener Sensoren auf Helgoland. MS Thesis, HafenCity University Hamburg, Germany

Lewis JR (1976) Long-term ecological surveillance: practical realities in the rocky littoral. Oceanogr Mar Biol Annu Rev 14:371-390

Lewis JR (1978) The ecology of rocky shores. Hodder and Stoughton, London

Lindegarth M, Aberg P, Cervin G, Nilsson P (2001) Effects of grazing on the structure of mid-shore, intertidal assemblages on moderately exposed shores of the Swedish west coast. Mar Ecol Prog Ser 212:29-38

Lintas C, Seed R (1994) Spatial variation in the fauna associated with Mytilus edulis on a wave-exposed rocky shore. J Molluscan Stud 60:165-174

Lubchenco J (1983) Littorina and Fucus: effects of herbivores, substratum heterogeneity, and plant escapes during succession. Ecology 64:1116-1123

Meijer AJM, Waardenburg HW (1994) Tidal reduction and its effects on intertidal hard-substrate communities in the Oosterschelde Estuary. Hydrobiologia 282-283:281-298

Menge BA (1976) Organization of the new England rocky intertidal community: role of predation, competition, and environmental heterogeneity. Ecol Monogr 46:355-393

Menge BA, Farrell TM, Olson AM, van Tamelen P, Turner T (1993) Algal recruitment and the maintenance of a plant mosaic in the low intertidal region on the Oregon coast. J Exp Mar Biol Ecol 170:91-116

Menge BA, Sutherland JP (1976) Species diversity gradients: synthesis of the roles of predation, competition, and temporal heterogeneity. Am Nat 110:351-369

Petersen CGJ (1914) Valuation of the sea. II. The animal communities on the sea-bottom and their importance for marine zoogeography. Rep Danish Biol Stn 21:1-44

Reichert K, Buchholz F (2006) Changes in the macrozoobenthos of the intertidal zone at Helgoland (German Bight, North Sea): a survey of 1984 repeated in 2002. Helgol Mar Res 60:213-223

Sánchez Í, Fernández C, Arrontes J (2005) Long-term changes in the structure of intertidal assemblages after invasion by Sargassum muticum (Phaeophyta). J Phycol 41:942-949

Stephenson TA, Stephenson A (1949) The universal features of zonation between tidemarks on rocky coasts. J Ecol 37:289-305

Stephenson TA, Stephenson A (1972) Life between tidemarks on rocky shores. Freeman, San Francisco

Vadas RL, Wright WA, Miller STL (1990) Recruitment of Ascophyllum nodosum: wave action as a source of mortality. Mar Ecol Prog Ser 61:263-272

Wiltshire KH, Manly BFJ (2004) The warming trend at Helgoland Roads, North Sea: phytoplankton response. Helgol Mar Res 58:269-273

Zhang B, Miller S (1997) Adaptive automatic terrain extraction. In: McKeown DM Jr, McGlone C, Jamet O (eds) Integrating photogrammetric techniques with scene analysis and machine vision. Proceedings of 11th SPIE's International Symposium on AeroSense. Orlando, Florida, pp 27-36 